\title{
JKAP
}

JKAP (Jurnal Kebijakan dan Administrasi Publik) Vol.22 (1), May 2018, 52-62

ISSN 0852-9213 (Print), ISSN 2477-4693 (Online)

Available Online at https://journal.ugm.ac.id/jkap

\section{"Wrong Majors' Phenomenon": A Challenge for Indonesia in Molding Glob- ally Competent Human Resources to Encounter Demographic Dividend}

\author{
Rizaldy Ali \\ Departement of International Relation Universitas Hasanuddin \\ rizaldy_ali@yahoo.com
}

\begin{abstract}
The growth of youth population has now become a strategic consideration of global trends predicted by 2030. In many parts of the world, the growth of youth population is increasingly uncontrolled. According to the Central Agency on Statistics, it revealed that Indonesia's population is dominated by a productive age group that is between 15-64 years old. This condition shows that Indonesia is moving into an era of demographic dividend. However, the fact that the human development index of Indonesia is too low; Indonesia ranked 110 out of 188 countries in the world and with massive numbers of academic unemployment, as if showing the unpreparedness of Indonesia in facing demographic dividend. This paper, attempts to highlight upon; the immense impact of mistaking majors to the human resource competence. Examine the key factors of wrong majors' phenomenon, and how do implications arise when students are incorrectly selected. The research used a descriptive method; source data ascribed to field research; and study of literature. Through this research, the most striking findings are: the key factors that trigger wrong majors' phenomenon that is caused by the influence of significant person statistics, low passing grade becoming their consideration to be accepted in college; they didn't gain any intensive preparation for going to college; the existence of consciousness upon the demands of experts, so that they preferred majors based on what the market needs not relying on their interest; and also the fears for not doing anything after graduating from high school. Mistaking majors implies towards the psychic of the college student; such as, highly vulnerable to being stressed because they are not able to adjust to the learning process.
\end{abstract}

Keywords: demographic dividend, human resource, wrong majors' phenomenon 


\section{INTRODUCTION}

At the present time, the escalation of unemployed graduates is rising to worrying levels in Indonesia particularly, regionally, and even in some high-growth economies. The most nonplus and highlighted query is that whether high-graduate unemployment reflects a chronic oversupply of graduates, although, plenty of job offers reveal that they could not seek people with the appropriate competence. Many experts emphasize that Asian countries should be concerned with not only expanding higher education but also ensuring quality in respect of graduate unemployment.

We may take South Korea as an example of a country, which has the number of economically-inactive graduates of over three million for the first time, suitable with government figures released on $3{ }^{\text {rd }}$ February, up just to over $3 \%$ from the previous year. The data that was produced by the Korea Statistics Agency states that in the worldscope, there are around eighty per cent-the uppermost university participation rates in Korea. Compared with fifteen to forty per cent for the most advanced economies (Sharma, 2014). As said by Kong Mi-Sook from the Korea Statistic Agency that the key reason for rising unemployment is because of the increasing number of college graduates. Other cases from India: India has seen a rush forward in graduate unemployment in the last couple of years. One-in-three graduates, up to the age of twenty-nine, was unemployed.

As revealed by the Labour Ministry's Youth Employment-Unemployment Scenario 2012-13; "In India, graduates spent much of their time accumulating different degrees and in due course realize that those degrees are not suitable with private sector jobs" (Alya, 2014).The tendency in this era, namely people have specially focused on education as being important and that it is just for fulfilling official requirements to obtain a job without considering how to be an expert in the majors they took; in fact they preferred randomly, not based on their passion or desire, but more likely based on trends or social constructions, that people with higher education will be powerful and respectful.

The numbers of undergraduates unemployed increased compared with previous years. Almost $30 \%$ of scholar graduates in Indonesia are not absorbed by the job offers, even the most dominant contributor to unemployment is the labor force of college graduates (Viva, 2010). This is in accordance with the facts presented by the Central Bureau of Statistics in the last three years (Figure 1).

The unemployment rate of highly educated people has increased in the last four years; in 2013 as many as 434,185; in 2014 as many as 495,143 ; in 2015 as many as 653,586 and in 2016 increased to 695,304 (Making, 2017, p. 112). According to Indonesia Statistics (BPS), the current population of Indonesia is dominated by the productive age group that is between 15-64 years old. This condition shows that Indonesia is in the era of demographic dividend.

Demographic dividend, defined by the UNFPA (United Nations Population Funds) meaning that: "the economic growth potential that can result from shifts in a population's age structure, mainly when the share of the working-age population (15 to $64)$ is larger than the non-working-age share of the population (14 and younger, and 65 and older)" (UNFPA, 2016). It is estimated that this demographic dividend era will reach its peak in the period 2020-2035, along with the era of demographic dividend that is very rare for one country, when the number of productive age of Indonesia is projected to be at the highest graph in history, reaching 67.9 percent of the total population of 297 Million people.

The declining of human-developmentindex (HDI) shows that Indonesia's position is ranked 110 out of 188 countries in the world with a score of 0.0684 , while in 
ASEAN region, HDI in Indonesia is in sixth place from 10 ASEAN countries, as if showing the unpreparedness of Indonesia in facing demographic dividend in the future. This position is still below the Philippines, Thailand, Malaysia, Brunei and Singapore (Purba, 2015). A report from the UNDP states that if observed the growth of Indonesia's human development index since 1980 has a significant increase of $44.3 \%$ from $0.474 \%$. However, within the last three years, the human-development-index is experiencing a slowdown in growth.

The abundant labor force in the demographic dividend phase should be optimized as much as possible by Indonesia, as the quality of the workforce will have a positive impact on the country. A quality workforce will be able to respond to world-standard work offerings.

The reality that is happening today in many developed countries that lack young residents like China, as reported by the Wall Street Journal (Friday, January 22, 2016), is that the number of workers aged 16-59 years decreased by 4,87 million (Huntnews, 2016). This decline in working age is coinciding with China's economic downturn. The fall in the number of workers triggers the scarcity of labor, increases labor costs and eliminates competitive advantages that can drive production and export growth. For that reason, demographic dividend opportunity must be utilized as much as possible to encourage economic improvement of Indonesia.

Surrounded by opportunities that may be obtained from the demographic dividend, there is also a fear that this may have different results. Demographic dividend can be a boomerang for Indonesia itself, but when the country is not ready to welcome demographic dividend until 2020-2035, it can cause new problems that are not less great. When Indonesia is unable to prepare a qualified workforce; the consequence is large scale unemployment. After India and Brazil, Indonesia ranks third as a country with a graduate growth of more than $4 \%$ and an average surplus of $1.5 \%$ per year. But, companies still find it difficult to get employees with high potential. Based on Willis Towers Watson's study of talent management and rewards since 2014, 8 out of 10 companies in Indonesia have difficulties getting readymade college graduates (Garawati, 2016). It is due to low competence and lack of soft skills possessed by the prospective workforce that the allocation of employment is not fully met. According to national labor survey data released by the National Planning Agency (Bappenas) in 2009, the high number of unemployed in Indonesia is currently very worrying. Open unemployment is dominated by diploma and university graduates with a range of over 2 million people. They are often called "academic unemployment due to 'majors' ".

'Wrong majors phenomenon', is a reality in which students who see themselves having no interest in what they learn daily in the class. They also have problems with lectures and grades. On the other hand, there is interest and talent derived from the classes, but constantly hidden because what they love to learn is different with what they learned. In general, people who are studying in high school or college, are still confused about the strides that must be taken in choosing a college, and career after college. Due to this perplexity, their ranges are affected by new information that leads them to ultimately determine a choice that essentially they do not know whether it is appropriate to their interests and talents, or not.

Another tendency, because most of the students are too quick to determine the areas of work to be cultivated without first doing self-reflection or take some time to think or cross-check the available work. So, when it is realized that they do not match with the work they are in, ultimately it will be difficult to be a professional person in the field or department that they involve in.

The rise of the new perspective is that we don't need to consider interest and passion in choosing majors at college; hence in 


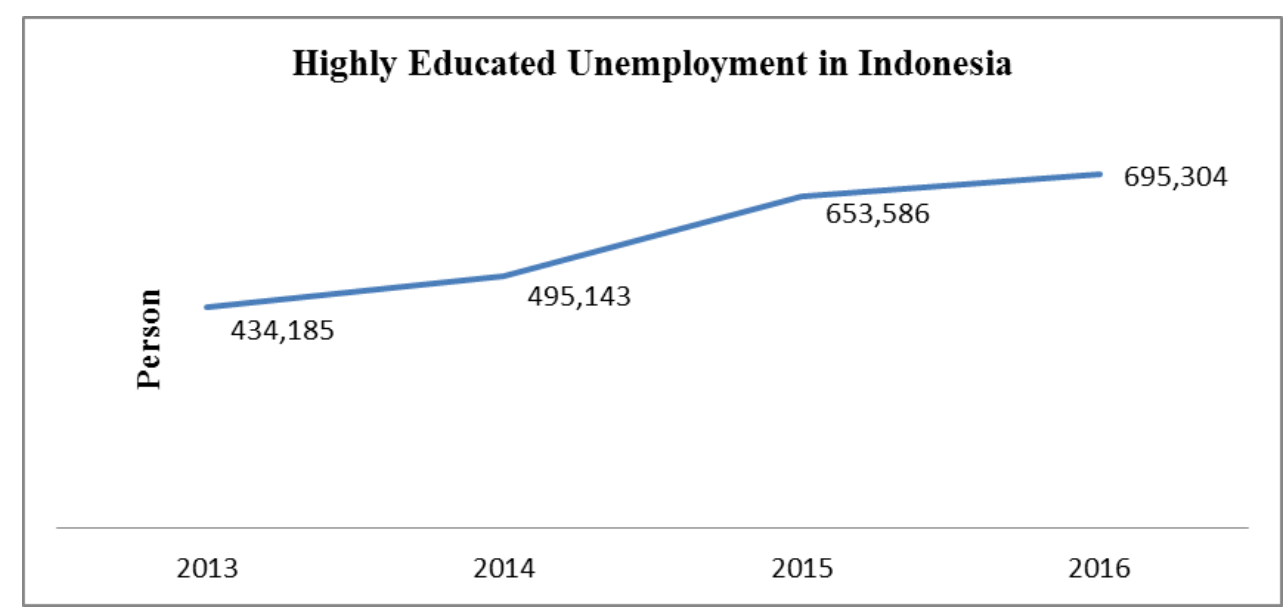

Figure 1. Savant Unemployment Data

Source: Data analysis

this competitive era, an appropriate job is extremely difficult to gain. In determining career, it must be adjusted with interest, or talent is no longer effective. However, as what Alisson Green stated on this topic namely, "Do what you love is privileged advice that ignores the fact that the majority of the world's population works to get food and housing, not for emotional or spiritual fulfillment. And even among the most socioeconomically privileged piece of the population, the segment that this advice is usually targeted to, it causes an awful lot of angst and even shame over not loving your career when people are telling you that you should "(Green, 2013). If doing what you love for a living becomes too stressful and you start to lose interest then, is there a possibility you never really loved it as much as you thought you did. Another problem that must be addressed is that; passion is a need, therefore, although we posses interests toward a particular sphere we still lack the key ingredients of job satisfaction. The research result has shown that you will still become unsatisfied. On the other hand, following a passion, potentially makes it harder to satisfy the other ingredient, hence, the sphere that you are passionate about, apparently becomes the most competitive.

As what (Carlson, 2003) said, that after being graduated by university, most indi- viduals do not understand what to do after graduation. These conditions become stressors for university graduates, and will cause anxiety. Being a member of the department as a community becomes important, which is generally feared by new students (or in Indonesia called MABA) who want to start lecture level. This type of factor, which brings someone into wrong majors and which make them perceive that they are wrong in determining majors at college, and the most common effect is the lack of enthusiasm in learning something we have chosen in a particular department. And as time passes, those who find themselves misguided in the lack of enthusiasm in learning a field, will find a variety of additional reasons such as; Incompatibility in social life, inability to follow a course, and so on.

According to the exposure above, this underpins for the author to formulate a problem to be studied in this paper, namely:

1. What are the main causes of wrong majors phenomenon?

2. What impacts arise when students went wrong in preferring their majors at college for themselves, and the impacts against the attainment of demographic dividend opportunities? 


\section{METHODS}

Research method that issued by the author in this research is the descriptive method. According to (Nazir, 1998), descriptive method is a method in examining the status of a group of people, an object, a set of conditions, a system of thought or a class of events in the present. The purpose of this descriptive study is to create a systematic description, factual and accurate facts, traits and relationships between the phenomenon under investigation.

\section{Source and Data Types}

\section{a. Primary data}

Primary data is a variety of information that ascribed from the parties who became research informant. On this research the type of data including information about the causes of mistaking majors, on how students went wrong in choosing their majors, and on how they underwent the campus life amidst the dilemma of incompatibility between them and their interest or passion. The research method that is used on this research is purposive sampling method. The subjects of this study are students of Hasanuddin University who have been perceiving impacts of mistaking majors. The number of samples on these studies are 60 students from various departments.

\section{b. Secondary Data}

Secondary data is data obtained through literature study. Such as books, journals, articles, magazines, handbooks, internet sites, institutes, and related institutions. As for the required data, this is data directly related to the author's research.

\section{Data Collection Techniques}

\section{a. Reader Review}

In data collection techniques, the author uses library research collection techniques (Library Research), by reviewing a number of literary works related to the problems studied in the form of books, journals, documents, articles in various media, both internet and daily newspapers.

\section{b. Questionnaire Technique}

A technique of collecting data indirectly (researchers do not directly ask questions with respondents). The instrument or data collection tool is also called a questionnaire containing a number of questions that must be answered or responded by the respondent (HB, 2006). Respondents have the freedom to provide answers or responses according to their perceptions or experiences.

\section{c. Interview}

Interview is an effort to collect information by asking a number of questions verbally to be answered verbally as well. The main feature of the interview is a face-toface relationship between the information seeker (interviewer or informant-hunter) with the source of information (HB, 2006).

\section{Data Analysis Techniques}

Data analysis techniques used by the author in analyzing the data of research results is a qualitative analysis technique; the basis of analysis is systemic analysis by trying to solve the problems being researched and develop information of the circumstances to be studied. Data collection aims to refine the ideas and to see the causes, analyze and portray conclusions (Robandi, 2008) Problems are illustrated based on existing facts, then connecting the facts with other facts to produce an appropriate argument.

\section{FINDINGS AND DISCUSSION}

\section{Causative Factors of Wrong Majors Phe- nomenon and Its Impacts}

\section{Effect of Significant Person}

Some of the students who have made the wrong choice in majors, are students who at the time of electing a major were not making this decision on personal choice, but their choices were influenced by the closest people, e.g., parents. Many have dismissed their wishes and aspirations because of the pressures of the immediate environment; such as their immediate family, parents, 
friends and other factors affecting them. The students that I interviewed chose their subjects for majors which were not based on their own choices. It is becoming a decision from parents in choosing majors for their child; namely these tend to be the majors that are considered to have good prospects in the future, such as: medical, civil engineering, teacher education, law, and that look familiar in the neighborhood and are considered well-established. Whereas in reality today, there are numerous departments opened in colleges that process the course inception based on the labor market demand. Beside that, parents, also have significant influence on the students' achievement (Yosai, 2017). This is particularly indicated that parents have an important role in improving children's achievement; for example, parents assist their children to interact with wide society, parents are the first teacher to educate their children, including determining every single choice that interlinked with their children's future life. To make sure that parents are enabled to undergo their roles in good ways, the parents must have a good educational background, understanding positive and negative sides of the policy that they make for their children.

In the case of students who already know their ideals, talents and interests but get intervention from various parties in the process of selecting majors, makes them encounter inner conflicts. That's because the parents choose the majors; which is not compatible with the student's interests and talents but based on the ambition of parents. So, the students just follow the lecturing process and try to adjust. According to the elucidation from child and adolescent psychology expert Dr. Charyna Ayu Rizkyanti, SPsi, MA., what I have cited in (national university page,2015) suggests that based on research conducted by the National University, the core problem of mistaking majors is still influenced by the lack of information about potential students. The main cause, some of them decided their majors choices depending on personal opinions that may not necessari- ly match the potential within them, including the influence of their friends. Charyna also explained that, during high school, teenagers processed in search of their identity. Although this is a common natural phase, the sensitivity of the environment, especially of the parents, is still needed. Caring parents will be able to detect changes of labile mind of adolescents, so that adolescents can avoid things that are negative and be able to develop their potential.

Thus, the teenager will be able to decide and choose the course according to his or her potential. This is referred to as: teenagers have found their true identity. Environmental factors, simultaneously and partially influence on achievement motivation. That is, environmental factors have an impact on the behavior patterns of a person included in decision-making. Research conducted by Karel Muskanan resulted in the findings that taking career insurance into consideration for someone to excel, they also need competence (Muskanan, 2015). Because, with the competence there will be the capital or guarantee for getting a better career.

\section{Passing Grade}

Awareness towards the existing jobs have set high qualifications for every job applicant. Bachelor's diploma becomes the minimum qualification to get a job at this time, and especially in the future it will become the trigger factor of senior high-school students to continue their education to college-bench. Because of the high qualification factors, it will make the students only focus on how to get into college. In the process of choosing a low passing-grade department, it becomes the main reference for some students, regardless of the prospect of work and scientific study.

When I took the college admission selection
test, in the preparation course place, my trial
result test at the course place exhibited that
my score was low, therefore my tutor said to
me that, I should adjust to the department, at
least fit with my score. Accidentally, Mathe-
matics major became one of the lists which
gave me a chance to be accepted in universi- 


\section{Rizaldy - Wrong Majors' Phenomenon." A Challenge for Indonesia ...}

ty. Whereas, I wanted to study in a Medical Faculty indeed, that is my ideal, because I want to be a doctor. (Aida, Student of Natural Sciences Unhas, 2016)

\section{Lack of Introduction Regarding University Profile to High School Students}

The lack of information obtained by students made them amiss in choosing majors. They are faced with confusion about the orientation and prospects of the courses available in the lecture. They do not know the source of the valid information regarding majors that they want to be selected. From some admissions of students who were interviewed by the author, they got information through the internet but the information obtained was quite trivial, just a basic introduction.

\begin{abstract}
At the school, my friends and I didn't get any information about the details or profile of college, lecturing process, materials and job prospects of every single college, especially, until the simulation test of talent before the National Examination (UN), there was a counseling initiated by students and learning guidance agencies, but information which was presented to us (gave) only a glimpse of the university profile, so I had to search for information on the internet and the data I obtained was only a small picture and that was not enough to guarantee its validity. (Ridha, Student of Civil Engineering Department of Unhas, 2016)
\end{abstract}

So, the problem posed when students are not given the initial understanding of profiles and department information is that they tend to have different perspectives on the subject they choose with what they think. The indicator is that, the usage of keywords on the college list that are often generalized by most students and misinformation obtained on the internet.

Wawanis a student from Social and Political Sciences is one of many Indonesian students who have the same case.

I studied at vocational high-school, majoring in accounting. I want to work in the government financial institutions such as the Financial Training Center. At the time, when I was confronted with numerous majors in a list of colleges, I chose the department of
State Administration, because in my mind, administration meaning is related to finance and my teachers also justified my assumptions. But, when I came in into the State Administration department, my assumption during the vocational high-school was a big mistake. So, I felt wrong in choosing this department. But because I have a chance to go to college, so I just live it even though I have to learn extra hard to understand the science study of this major. (Satriawan, Student of State Administration Unhas, 2014).

\section{Prospect of Work as Consideration}

Careful attention to the needs of the labor market and job prospects is a positive matter only considering the prospects of work without adjusting between interests and talents with majors that the students have been wrestling. This case made students faced with the problem of inability to follow the learning process and absorb the knowledge taught. That incapacity, triggers symptoms of psychological distress such as depression and stress; this certainly has a negative impact on the development of student's potential, because they cannot adjust to the lecture. An individual's interest in a particular field or object affects the process of individual cognition and affection. Interest influences individual learning in several stages (Hidi, S. \& Renninger, 2006). Ultimately, this interest affects goal setting.

\begin{abstract}
I worked for two years but I was thinking to go to college, hence I want to improve my career ladder in the future. When I worked, I served in data-processing, so I decided to continue my education to college and majoring in Statistics. I realized that my passion was in language, but I see a good prospect of work in Statistics; but after a few semesters, my college life as a Statistics student became overwhelming in absorbing and following the learning process. I just realized that I do not fit with this; I am a bit depressed and stressed when the tasks piled up and I haven't understood yet. (Yuris, Student of Statistics Department Unhas, 2015)
\end{abstract}

As Susilowati (2009) mentioned, several problems could arise when students are mistaking majors, namely; psychological problems, academic and relational problems. Psychological problems are indicated by feelings of discomfort when receiving lec- 
tures that are perceived to be inconsistent with interest or talent, academic problems are demonstrated by non-optimal performance, while relational problems arise when students withdraw from their environment because they feel uncomfortable with the lecture situation (Intani \& Surjaningrum, 2010). Mistaking majors also has an impact on the appearance of disappointment and regret. If it can not be addressed properly, this can lead to the emergence of stress, and will affect productivity of students in college.

\section{Evading Saturation After Senior High School Graduation}

Avoiding saturation without activity, not having rushes at home after finishing high school education, became one of the reasons of someone to study in the university. One of the interviewees said that the prelection was not my preferred activity but only an escape to avoid boredom.

My desire to study at college just occurred to me when I was in the last year of highschool. After all, seeing friends who were all busy talking about lectures and to be honest, I didn't know what I wanted to do after high school. So, I decided to go to college. Initially, I tried to find information on the internet. The keywords that I entered in the Google search box namely "the most cozy majors" (jurusan paling enak), why? Because I couldn't force myself to learn, even before I did not plan to go to college. I am a type of bored person, my browsing results ended up finding social and political sciences and literature as the departments that became my consideration. In the midst of a dilemma in choosing majors, I had time to pray in my heart; Oh God, who am I ? I didn't know myself, what stands out from me? what can I do?. I have attended various courses such as piano class, voice instruction courses, but none of them are comfortable or fit with me. I dislike to be dictated to, and I would love to directly practice right away. After I attended Unhas and lived college life for six semesters, I found it difficult to adjust, simply because I did not like to sit in class and listen up to lecturer's explanations. I like to practice right away. I thought about dropping out of college early, but I've got a lot of friends here, and they often give me the mo- tivation to stay in college up to graduation; they are my reasons why I stay here. After lecturing at Unhas I will take cooking class, surely far apart with International Relations. (Nabila, Student of International Relation Unhas, 2014)

Some people go to college to improve their self-capability and get a decent job, but in Nabila's case, the author found out that there is someone who came into college, just to avoid boredom. Unfamiliar passion is an anxiety for some people because they do not know what is their natural talent. When people are faced with such a situation, then they will only follow the flow of life as others do without being themselves.

\section{Less Preparation to Face College Entrance Screening Test}

Although students have known their talent and interest since early childhood, but not accompanied with ripe preparation to face a college entrance-screening test; it is also a leading factor for not being accepted on the compatible major with the talent and interest. From the few cases that the author observed, students who mistook majors are those who put their current majors in the third or second choice at the college entrance test. Meaning that the majors they are in now are not priority to reach their goals, not in accordance with their talents and interests but based on their fear if they are not accepted in the university.

I love learning the new language. I find it easy to absorb foreign languages. Since high school I aspire to become a teacher, and to achieve these goals, I have to study English. But at the time of my college entrance test I was declared failed to study in English Literature, and I was accepted in Biology majors at Hasanuddin University (Unhas) instead. Whereas I chose Biology in the third position on the college majors' list. The obstacle that I've been facing today is that, I feel very left behind with other friends because I do not have basic skills for biology. This year I plan to retake SBMPTN (college entrance test) I wish will be accepted in English literature. (Atika, Student of Biology Unhas, 2015) 


\section{Rizaldy - Wrong Majors' Phenomenon." A Challenge for Indonesia ...}

Impact towards the Attainment of Demographic Dividend Opportunities

Choosing a college major is basically a process that has been started since childhood. The chance, stimulation, experience of any child since childhood is optimum and consistent, it will be a provision, capital and foundation of interest and talent. The more the exposure is, the more will children know about themselves, but the less exposure, the less will be the child's knowledge of themselves. According to those who experience the wrong majors, they certainly will not be able to become experts in their field because they undergo majors or fields that were cultivated and not based on interest or passion. Demographic dividend requires experts to be absorbed into the employment sector or at least able to create their own jobs. If we look at the context of Indonesia with a high population level and the existence of high qualifications determined by the employer, and the existence of this mistaking majors phenomenon; it will create many college graduates who are less qualified, so difficult to be absorbed by employment and, of course, this will have an immense impact for unemployment progress.

Globalization comes with full complexity and competition. High quality human resources are needed in order to encourage a development aspect. When a person is incapable in adjusting, due to lack of skill or ability, he/she will naturally be eliminated. Thomas Friedman, author and newspaper columnist of the New York Times, who became one of the central figures of globalization pro, expressed his view that globalization is a necessity. Its presence in the modern world is inevitable and a fact to be understood. The development of the internet (worldwide web) has linked communities from various parts of the world thus eliminating the barriers and boundaries of the country. Cited by Yuniarto in Mubah (2010) that some experts such as Roland Robertson and David Held, for example, they said that the development of globalization is not really a new thing and has started since the era of empire in the 15th century and developed with the formation of nation state in the $17^{\text {th }}$ century (Yuniarto, 2014).

Literally, globalization comes as a solution to demographic dividend: what does it mean? Giving the opportunity that globalization for every single human can advance their self, to be equal with others, and to gain proper life. How, nowadays, we are no longer limited to self-development, one can easily learn and work even abroad, innovate and create new jobs. It means we have a wider space to explore ourselves. One of the concepts of globalization that the author deems relevant to the improvement of global skills is the concept of universalization. Universalization is equality or no differentiation, as a result of global impact of globalization as a whole. So, universalization is different from globalization. Universalization is more concerned with everything that is equal to one another. To achieve the equality aspect in the era of globalization, it is necessary for the strength of competitiveness. The strength begins with strengthening human resources that are the spearhead to increase the competitiveness of the nation. Therefore, the formulation of human resource characteristics is required in the global era to gain benefits of demographic dividend.

Demographic dividend will offer benefits for a country as long as this is coupled with competent human resources. The competencies in question are human resources that have an open competitiveness with other countries, adaptive and anticipatory to new changes and conditions, open to change, able to learn how to learn, multiskilling, easy to retrain, and have the fundamentals of a broad, powerful, and fundamental capacity to develop in the future ( $\mathrm{J}$. Y. J, 2009).

\section{Global competence is defined as:}

\footnotetext{
"the knowledge and skills that help people understand the flat world in which they live, the skills to integrate across disciplinary domains to comprehend global affairs and events and to create possibilities to address them"(Reimers, 2013).
} 
That is, knowledge and skills that help people understand the flatness of the world in which they live, the skills in integrating interdisciplinary studies to understand global activities and settings and create the possibility of interacting with the global world. In general, it is understood that global competence is an attitude and ethical adjustment, enabling us to interact comfortably, respectfully, and productively with different human beings from different geographical places.

There are three dimensions in developing global competence: First, attitudes, values and skills reflected through openness, interest, and positive disposition on the variations of human cultural expressions that are reflected internationally and within the global value framework. Second, the ability of foreign languages. And third, encompasses disciplinary knowledge in comparative scopes such as historical comparisons, anthropology, political science, economics and commerce, literature, world history and the ability to integrate all disciplines in thinking and solving problems about aspects of the globalization process.

\section{CONCLUSION}

This research argues that the actual size of academic unemployment is caused in one way, specifically, due to mistakes in choosing majors, so the students are not able to optimize themselves and explore their self potential, and because of the lack of skill, impacting academic unemployment. The leading factors of mistaking majors are: influence of significant person, less preparation to face college entrance screening test, lack of introduction at the University to high -school students, prospect work consideration, evading saturation after Senior HighSchool graduation. Mistaking majors have psychological implications for college students. Students are stressed and depressed because they are unable to adjust to the learning process. In addressing the error dilemma in choosing majors; there are students who are trying to get out of their cur- rent majors by excuse retaking the entrance test in the new school year, they are also just trying to live it and think of it as a way of life. The presence of globalization as a benchmark that the world is moving towards is a more massive change, so that it has become a reflection of how competent human resource roles can help the country achieve its development aspect. In order to improve the quality of Indonesian human resources as one of Indonesia's development indicators, it is very necessary to pay attention to the productive age population; especially students to be able to optimize their potential and talents through the provision of adequate and accurate information, as well as providing direction on labor market demand and supply, and what is important is that the country should be prepared to answer the challenge of demographic dividend and the existence of Indonesia in global competition

\section{REFERENCES}

Alya, M. (2014). mishra. Retrieved April 1, 2017, from http:// www.universityworldnews.com/ article.php? story $=20140204171742828$

Badan Pusat Statistik. (2017). Laporan Perekonomian Indonesia. BPS, Subdirektorat Publikasi dan Kompilasi Statistik. Jakarta: CV NARIO SARI.

BAPPENAS. (2009). Angka Pengangguran Akademik Lebih dari Dua Juta. Retrieved January 20, 2017, from BAPPENAS Website: www.bappenas.go.id

Carlson, R. (2003). Don't sweet guide for graduates. Jakarta: PT. Gramedia Pustaka Utama.

Garawati, M. (2016). Kenapa Lulusan Perguruan Tinggi Makin Susah Mendapat Pekerjaan - Kompas. Retrieved April 13, 2017, from http:// edukasi.kompas.com/read/2016/ 04/23/17424071/

Kenapa.Lulusan.Perguruan.Tinggi.Makin.S usah.Mendapat.Pekerjaan.

Green, A. (2013). Why You Shouldn't Follow Your Passion _ On Careers _ US 
Rizaldy - Wrong Majors' Phenomenon." A Challenge for Indonesia...

News. Retrieved from http:// money.usnews.com/money/blogs/ outside-voices careers/2013/ 04/17/ why-you-shouldnt-follow-yourpassion

HB, S. (2006). Metode Penelitian Kualitatif. Surakarta: UNS Press.

Hidi, S. \& Renninger, A. (2006). The FourPhase Model of Interest Development, 41(2), 111-127.

Huntnews. (2016). Penduduk Usia Kerja Susut, China Terancam Kekurangan Pekerja. Retrieved January 28, 2017, from http://www.huntnews.id/ p/ detail/318447799175201? ucparamstr $=$ dnfrpfbivesscpgimibtbmntnijblauputoggdnw\&pos $=14687321041$ 81\&channel=tagheadlines\& chncat=tag sindonesian.

Intani, F. S., \& Surjaningrum, E. R. (2010). Coping Strategy pada Mahasiswa Salah Jurusan, 12(2), 119-127.

J. Y. J, N. (2009). Pre Employment Skills Development Strategies in the OECD. Washington: USA: Social Protection Labor (The World Bank).

Muskanan, K. (2015). Analisis Motivasi Berprestasi Atlet Pusat Pendidikan dan Latihan Olahraga Pelajar ( PPLP ) Provinsi Nusa Tenggara Timur. Jurnal Kebijakan \& Administrasi Publik, 19 (2), 105-113. Retrieved from http:// journal.ugm.ac.id/jkap

Making, S. T. (2017). Pengaruh Pertumbuhan Ekonomi, Investasi dan Upah Minimum Provinsi Terhadap Tenaga Kerja Berpendidikan Tinggi di Indonesia. Diajukan sebagai Tugas Peneitian Skripsi. BPS, Subdirektorat Indikator Statistik. Yogyakarta: Universitas Shanata Dharma.

Nazir, M. (1998). Metode Penelitian. Jakarta: Ghalia Indonesia.

Purba, R. (2015). Bonus Demografi_Pisau Bermata 2 bagi Indonesia_oleh RJ Purba - Kompasiana. Retrieved April 17, 2017, from http:// www.kompasiana.purba/bonusdemografi-pisau-bermata-2bagiindone- sia54f431897455137a2b6c887e

Reimers, F. M. (2013). century. Many of these competencies dovetail with and extend the competencies necessary to the exercise of responsible and engaged citizenship. Global education is, in this sense, the new civics of the 21 , (October), 1-15.

Robandi, I. (2008). Becoming the winner: Riset, Menulis Ilmiah, Publikasi Ilmiah dan Presentasi. Yogyakarta: CV. Andi Offset.

Sharma, Y. (2014). sharma. Retrieved April 1, 2017, from http:// www.universityworldnews.com/ article.php?story $=20140213153927383$

Susilowati, P. (2009). Memilih Jurusan di Perguruan Tinggi. Retrieved January 24, 2017, from E-Psikologi Website: http://www.psikologi.com

UNFPA. (2016). UNFPA. Retrieved April 13, 2017, from http://www.unfpa.org/ demographic-dividend

Universitas Nasional. (2015, May 28). Kenali Karakter Sebelum Memilih Jurusan. Retrieved March 2, 2017, from Universitas Nasional Progdi Agroteknologi: http://agroteknologi. ftan.unas.ac.id/kenali-karaktersebelum-memilih-jurusan/

Viva. (2010, May 10). Lebih dari 1,2 Juta Sarjana Jadi Penganggur. Retrieved January 15, 2017, from Viva Media News Website: https:// www.viva.co.id/berita/bisnis/150011pilih-pilih-kerja-1-2-juta-sarjananganggur.

Yosai, S. (2017). The Influence of Parental Involvement, Classified By Parent's Demographic Factors, and Current Education Policy on Student Achievement in High School in NongChok District, Bangkok, Thailand. JKAP (Jurnal Kebijakan Dan Administrasi Publik), 20(2), $1 . \quad$ https:// doi.org/10.22146/jkap.12518

Yuniarto, P. R. (2014). Masalah Globalisasi di Indonesia: Antara Kepentingan, Kebijakan, dan Tantangan, Vol. 5, No (1), 29. 